\title{
Climate Change and Wheat Production in Drought Prone Areas of Bangladesh - A Technical Efficiency Analysis
}

\author{
Zarin Tasnim ${ }^{1}$, ASM Golam Hafeez ${ }^{1} \&$ Shankar Majumder ${ }^{2}$ \\ ${ }^{1}$ Department of Agricultural Finance, Bangladesh Agricultural University, Mymensingh, Bangladesh \\ ${ }^{2}$ Department of Agricultural Statistics, Bangladesh Agricultural University, Mymensingh, Bangladesh \\ Correspondence: ASM Golam Hafeez, Department of Agricultural Finance, Bangladesh Agricultural University, \\ Mymensingh-2202, Bangladesh. Tel: 880-91-67401-2737. E-mail: ghkennedy01@yahoo.com
}

\author{
Received: September 18, 2014 Accepted: October 19, 2014 Online Published: December 15, 2014 \\ doi:10.5539/jas.v7n1p43 URL: http://dx.doi.org/10.5539/jas.v7n1p43
}

\begin{abstract}
The present study aims at measuring the technical efficiency of wheat production under changing climate in drought prone areas of Bangladesh. The study employed farm level cross sectional data taken from 100 farmers using purposive random sampling technique from three upazilas of Thakurgoan district of Bangladesh. The study considered two successive years 2006 and 2007 as drought and normal year respectively on the basis of farmers' opinion and information collected from meteorological station. Semi-logarithmic regression model with dummy variable was used to estimate production variability of wheat due to drought. The findings showed that wheat production decreased by 17.4 percent on an average due to drought occurrence in the study areas. Cobb-Douglas stochastic frontier production function was used to determine the technical efficiency of the wheat growers and the factors which influence technical efficiency in wheat production. The empirical results of technical efficiency model showed that the effects of seed, pesticide, tillage, irrigation and fertilizer costs were significant in the production of wheat. Education, family size, farming experience, credit, extension- contact and farm size had negative effects on technical inefficiency of farmers which indicates that technical inefficiency decreases with the increase of these factors in both normal and drought years. The mean technical efficiencies were 67.00 and 86.40 percent in normal and drought years respectively. The results also indicate a good potential for increasing wheat production by 33 and 14 percent in normal and drought years respectively using the available resources and technology. Wheat farmers should give more attention to their farming practices and should take rationale decision for using farm resources efficiently.
\end{abstract}

Keywords: wheat, technical efficiency, climate change, drought

\section{Introduction and Background}

The economy of Bangladesh is primarily dependent on agriculture which contributes about 20.83 percent to the country's GDP (BBS, 2008). About 48.1 percent of the labour force is employed in agriculture (BBS Labour Force Survey 2005-2006). Bangladesh is frequently cited as one of the most vulnerable countries to climate change because of its disadvantageous geographic location, flat and low-lying topography, high population density, high levels of poverty, reliance of many livelihoods on climate sensitive sectors, particularly agriculture. Many of the anticipated adverse effect of climate change, such as sea level rise, higher temperature, enhanced monsoon precipitation and an increase in drought intensity, will aggravate the existing stresses that already impede the development of Bangladesh, particularly by reducing food security (Quazi \& Quddus, 2010).

Along with climate variability high growth rate of population makes the situation worse. Arable land decreases as the demand for habitation and industrial use increases. Food security and food self-sufficiency of the country face continuous threats from these major problems.

To ensure food security, increased wheat production can play a significant role. Wheat is the second most important cereal crop in Bangladesh (Craig, 1992). The crop sector contributes 11.61 percent the country's GDP of which major portion is contributed by wheat (BBS, 2008). Before 1975, the amount of wheat was very little (0.08 metric ton/ha) (BBS, 1980). Now-a-days wheat yields significantly increased to $2.17 \mathrm{metric}$ ton/ha in 2007-08 (FPMU, 2008).

Wheat has a significant importance in Bangladesh's economy in terms of production, food security and 
employment generation. Wheat is also important for providing nutrition to the people of Bangladesh. Like other food grains, wheat output could be increased efficiently by utilizing the productive inputs such as land, labour and capital. As there is limited scope for further increase of wheat area, production can be increased by increasing the technical efficiency of wheat with the existing technology.

Technical efficiency refers to the ability of a farm to produce maximum possible output from a given set of inputs under certain production technology. A technically efficient farm will operate on its frontier production function (Khan et al., 2010). Thus it is an indicator of productivity of the farm and the variation in technical efficiency can reflect the productivity differences among the farms. Technical inefficiency refers to failure of a farm to operate on the production frontier.

Understanding the determinants of socio-economic inefficiency of wheat production is very important for both farmers and policy makers to increase the productivity of wheat under changing climate situation in Bangladesh. Therefore, the present study was conducted to measure technical efficiency of wheat production under changing climate in drought prone areas of northwest Bangladesh with the specific objectives: i) to assess production variability of wheat due to adverse effect of climate change; and ii) to estimate the technical efficiency of wheat production under changing climatic condition.

\section{Methodology}

\subsection{Selection of Area, Sample and Sampling Technique}

Drought is a common phenomenon in the northwestern districts of Bangladesh (Banglapedia, 2003). For the present study, Thakurgoan district was purposively selected from drought prone agro ecological zone (AEZ) of northwest Bangladesh. Thakurgoan is one of the largest wheat producing areas in the northwestern region of Bangladesh. By following the same logic of concentration of wheat production, three upazilas of Thakurgoan district namely Thakurgoan sadar upazila, Pirganj upazila and Ranisankail upazila were purposively selected. For selection of sample, a list of the wheat growers in the selected upazilas was prepared with the help of extension officials of the upazilas. Simple random sampling technique was used to draw samples from the list. A total of 100 sample farmers comprising 35 each from Thakurgoan sadar and Pirganj upazila and 30 from Ranisankail upazila under Thakurgoan district. Data were collected by using pre-tested interview schedules through direct interview method considering two years - 2006 and 2007. These two successive years 2006 and 2007 were considered as drought and normal year respectively on the basis of farmers' opinion and information collected from meteorological station. The survey was conducted during the period of September-October, 2009. The collected data were then summarized, tabulated and analyzed according to the objectives set for the study.

\subsection{Analytical Techniques}

\subsubsection{Production Variability Analysis}

Semi-logarithmic regression model with dummy variable was used to estimate production variability of wheat due to drought occurrence in the study areas. In this regression model production was considered as the dependent and the drought considered as independent variable. Production of wheat varied extremely due to drought between two selected seasons. The existence of extreme values of dependent variable (production) leads to employ semi-logarithmic regression model for the study which provides higher values of coefficient of multiple determination $\left(\mathrm{R}^{2}\right)$.

To estimate the production variability of wheat the following semi-logarithmic regression model was proposed:

$$
\ln \mathrm{Y}=\beta_{0}+\beta_{1} \mathrm{D}_{1}+\mathrm{U}
$$

Where,

$\ln =$ Natural logarithm; $\mathrm{Y}=$ Output of wheat $(\mathrm{kg} / \mathrm{ha}) ; \mathrm{D}_{1}=$ Dummy for drought $(1=$ drought occurrence in the study area; $0=$ otherwise); $\beta_{1}=$ Slope coefficient of dummy for drought; $U=$ Random error term.

\subsubsection{Technical Efficiency Analysis}

Farrell (1957) was the pioneer of the frontier measure of efficiency which reflects actual farm performance and can include all relevant factors of production. Farrell's article on efficiency measurement led to the development of several approaches to efficiency and productivity analysis. Among these the stochastic frontier production (Aigner et al., 1977); (Meeusen and van den Broeck) and Data Envelopment Analysis (DEA) (Chamse et al., 1978) are the two principal methods. As noted by Coelli et al. (1998), the stochastic frontier is considered more appropriate than DEA in agricultural applications, especially in developing countries, where the data are likely to be heavily influenced by the measurement errors and the effects of weather conditions, diseases, etc. 
Thus following Aigner et al. (1977) and Meeusen and van den Broeck (1977), the stochastic frontier production with two error terms can be modeled as:

$$
\mathrm{Y}_{\mathrm{i}}=f\left(\mathrm{X}_{\mathrm{i}}, \beta\right) \exp \left(\mathrm{V}_{\mathrm{i}^{-}} \mathrm{U}_{\mathrm{i}}\right)
$$

Where $Y_{i}$ is the production of the $i$-th farm $(i=1,2,3 \ldots n) ; x_{i}$ is a (lxk) vector of functions of input quantities applied by the $\mathrm{i}$-th farm; $\beta$ is a $(\mathrm{kxl})$ vector of unknown parameters to be estimated; $\mathrm{V}_{\mathrm{i}}, \mathrm{s}$ are random variables assumed to be independently and identically distributed $\left(\mathrm{N}\left(0, \delta^{2}{ }_{\mathrm{v}}\right)\right.$ and independent of $\mathrm{U}_{\mathrm{i}} \mathrm{s}$ and the $\mathrm{U}_{\mathrm{i}} \mathrm{s}$ are non-negative random variables, associated with technical inefficiency in production assumed to be independently and identically distributed and truncations (at zero) of the normal distribution with mean $Z_{\mathrm{i}} \delta$ and variance $\sigma_{\mathrm{u}}^{2}$ $\left(\left|\mathrm{N}\left(\mathrm{Z}_{\mathrm{i}} \delta, \sigma_{\mathrm{u}}^{2}\right)\right|\right) ; \mathrm{Z}_{\mathrm{i}}$ is a $(\mathrm{lxm})$ vector of farm specific variables associated with technical inefficiency and $\delta$ is a (mxl) vector of unknown parameters to be estimated (Sharma \& Leung, 1998).

The first error component $\mathrm{V}$ is intended to capture the effects of random shocks outside the farmer's control, measurement error and other statistical noise and the second error component $U$ is intended to capture the effects of technical inefficiency.

Following Battese and CoeIli (1995), the technical inefficiency effects, $U_{\mathrm{i}}$ in Equation (2) can be expressed as:

$$
\mathrm{U}_{\mathrm{i}}=\mathrm{Z}_{\mathrm{i}} \delta+\mathrm{W}_{\mathrm{i}}
$$

Where $\mathrm{W}_{\mathrm{i}}$ are random variables, defined by the truncation of the normal distribution with zero mean and variance $\sigma_{u}^{2}$, such that the point of truncation is $Z_{i} \delta$, i.e $W_{i} \geq-Z_{i} \delta$. Beside the farm-specific variables, the $Z_{i}$, variables in Equation (3) may also include input variables in the stochastic production frontier (2), provided that the inefficiency effects are stochastic. If $Z_{i}$ variables also include interactions between farm-specific and input variables, then a Huang and Lie (1994) non- neutral stochastic frontier is obtained.

The technical efficiency of the $\mathrm{i}$-th sample farm, denoted by $\mathrm{TE}_{\mathrm{i}}$ is given by:

$$
\mathrm{TE}_{\mathrm{i}}=\exp \left(-\mathrm{U}_{\mathrm{i}}\right)=\mathrm{Y}_{\mathrm{i}} / \mathrm{f}\left(\mathrm{X}_{\mathrm{i}}, \beta\right) \exp \left(\mathrm{V}_{\mathrm{i}}\right)=\mathrm{Y}_{\mathrm{i}} / \mathrm{Y}_{\mathrm{i}}{ }^{*}
$$

Where $Y_{i}{ }^{*}=f\left(X_{i}, \beta\right) \exp \left(V_{i}\right)$ is the farm specific stochastic frontier. If $Y_{i}$ is equal to $Y_{i}{ }^{*}$ then $\mathrm{TE}_{\mathrm{i}}=1$, reflects $100 \%$ efficiency. The difference between $Y_{i}$, and $Y_{i}{ }^{*}$ is embedded in $U_{i}$. If $U_{i}=0$, implying that production lies on the stochastic frontier, the farm obtains its maximum attainable output given its level of input. If $\mathrm{U}_{\mathrm{i}}<0$, production lies below the frontier-an indication of inefficiency (Khan, 2003; Khan et al., 2010).

The maximum likelihood estimate (MLE) of the parameters of the model defined by Equations (2) and (3) and the generation of farm-specific TE defined by Equation (4) are estimated using the computer program FRONTIER 4.1 (Coelli, 1994). The efficiencies are estimated using a predictor that is based on the conditional expectation of exp $(-\mathrm{U})$ (Battese and Coelli, 1993; Coelli, 1994). In the process, the variance parameters $\sigma_{\mathrm{u}}^{2}$ and $\sigma_{\mathrm{v}}^{2}$ are expressed in terms of the parameterization:

$$
\sigma^{2}=\left(\sigma_{u}^{2}+\sigma_{v}^{2}\right)
$$

and

$$
\gamma=\left(\sigma_{\mathrm{u}}^{2} / \sigma_{\mathrm{v}}^{2}\right)
$$

The value of $\gamma$ ranges from 0 to 1 with values close to 1 indicating that random component of the inefficiency effects makes a significant contribution to the analysis of the production system (Coelli \& Battese, 1996).

The use of a generalized likelihood ratio test is another way of testing if inefficiency effects exist in the model. This is used in testing the significance of the model as the F-test in the Ordinary Least Squares (OLS) estimation. It can also be used in testing the functional form of the model (e.g., Cobb-Douglas versus Translog) and is more or less equivalent to the Chow test (Green, 1990; Johnston, 1984) in OLS estimation. The generalized likelihood ratio test statistic is defined by:

$$
\lambda=-2 \log \left[\mathrm{L}\left(\mathrm{H}_{\mathrm{o}}\right) / \mathrm{L}\left(\mathrm{H}_{1}\right)\right]
$$

Where $\mathrm{L}\left(\mathrm{H}_{0}\right)$ is the value of the log-likelihood function of a restricted model as specified by a null hypothesis $\mathrm{H}_{0}$ and $\mathrm{L}\left(\mathrm{H}_{1}\right)$ is the value of the log-likelihood function of an alternative hypothesis $\mathrm{H}_{1}$. The test statistic has a mixed $\chi 2$ distribution with degrees of freedom ( $\mathrm{df}$ ) equal to the difference between the number of parameters involved in $\mathrm{H}_{0}$ and $\mathrm{H}_{1}$ (Khan et al., 2010).

i) Empirical Cobb-Douglas stochastic frontier production function model

Two types of functions namely Cobb-Douglas and Translog dominate the technical efficiency literature. Since the sample number is not very high the Translog specification could not be used. The stochastic production function of Cobb-Douglas form for the sample wheat growers was specified as: 


$$
\ln \mathrm{Y}=\beta_{0}+\beta_{1} \ln \mathrm{X}_{1}+\beta_{2} \ln \mathrm{X}_{2}+\beta_{3} \ln \mathrm{X}_{3}+\beta_{4} \ln \mathrm{X}_{4}+\beta_{5} \ln \mathrm{X}_{5}+\beta_{6} \ln \mathrm{X}_{6}+\beta_{7} \ln \mathrm{X}_{7}+\beta_{8} \ln \mathrm{X}_{8}+\mathrm{V}_{\mathrm{i}^{-}} \mathrm{U}_{\mathrm{i}}
$$

Where,

In = Natural logarithm; $Y=$ Observed farm output $(\mathrm{kg} / \mathrm{ha}) ; \mathrm{X}_{1}=$ Area under wheat cultivation $(\mathrm{ha}) ; \mathrm{X}_{2}=\mathrm{Seed}$ $(\mathrm{kg} / \mathrm{ha}) ; \mathrm{X}_{3}=$ Human labour (man-days $\left./ \mathrm{ha}\right) ; \mathrm{X}_{4}=$ Pesticide $(\mathrm{kg} / \mathrm{ha}) ; \mathrm{X}_{5}=$ Tillage cost $(\mathrm{Tk} / \mathrm{ha}) ; \mathrm{X}_{6}=$ Irrigation cost $(\mathrm{Tk} / \mathrm{ha}) ; \mathrm{X}_{7}=$ Manure $(\mathrm{kg} / \mathrm{ha}) ; \mathrm{X}_{8}=$ Fertilizer $(\mathrm{kg} / \mathrm{ha}) ; \beta_{\mathrm{i}}=$ Unknown parameters to be estimated; $\mathrm{V}_{\mathrm{i}^{-}} \mathrm{U}_{\mathrm{i}}=\mathrm{Error}$ terms.

ii) Technical inefficiency effect model

The technical inefficiency effects $U_{i}$ 's in Equation (8) are defined as

$$
\mathrm{U}_{\mathrm{i}}=\delta_{0}+\delta_{1} \mathrm{Z}_{1}+\delta_{2} \mathrm{Z}_{2}+\delta_{3} \mathrm{Z}_{3}+\delta_{4} \mathrm{Z}_{4}+\delta_{5} \mathrm{Z}_{5}+\delta_{6} \mathrm{Z}_{6}+\delta_{7} \mathrm{Z}_{7}+\mathrm{W}_{\mathrm{i}}
$$

Where,

$Z_{1}=$ Education level (Years of schooling); $Z_{2}=$ Family size (Persons /family); $Z_{3}=$ Farming experience (Years); $Z_{4}=$ Dummy for credit $(1=$ credit receiver; $0=$ otherwise $) ; Z_{5}=$ Dummy for extension contact $(1=$ linkage with extension service; $0=$ otherwise $) ; Z_{6}=$ Dummy for training $(1=$ trained; $0=$ otherwise $) ; Z_{7}=$ Farm size $($ ha $) ; \delta_{\mathrm{i}}=$ Parameters of the respective technical inefficiency variable to be estimated $(\mathrm{i}=1,2, \ldots 7) ; \mathrm{W}_{\mathrm{i}}=$ Unobservable random variables or classical disturbance terms

iii) Hypotheses testing

The model for inefficiency effects mentioned in Equation (9) can only be estimated if the inefficiency effects are stochastic and have a particular distributional specification. Hence there is interest in testing the null hypotheses that

1) The inefficiency effects are not present, i.e., $\mathrm{H}_{0}: \gamma=\delta_{0}=\ldots \delta_{7}=0$; and,

2) The coefficients of the variables in the model for the inefficiency effects are zero, i.e., $\mathrm{H}_{0}: \delta_{1}=\ldots \delta_{7}=0$.

These null hypotheses were tested using generalized likelihood ratio test statistic $\lambda$, defined by:

$$
\lambda=-2\left[\log \left[\mathrm{L}\left(\mathrm{H}_{\mathrm{o}}\right) / \mathrm{L}\left(\mathrm{H}_{1}\right)\right]=-2\left[\log \left\{\mathrm{L}\left(\mathrm{H}_{\mathrm{o}}\right)\right\}-\log \left\{\mathrm{L}\left(\mathrm{H}_{1}\right)\right\}\right]\right.
$$

Where $\mathrm{L}\left(\mathrm{H}_{0}\right)$ and $\mathrm{L}\left(\mathrm{H}_{1}\right)$ are the values of the log-likelihood function for the specification of the null hypothesis and alternative hypothesis respectively.

\section{Result and Discussion}

\subsection{Production Variability of Wheat Due to Climate Change}

Drought greatly affects wheat production in the study areas of Bangladesh. Wheat is grown during the dry season (November to March), usually after the aman harvest, in competition with other crops such as dry season boro rice. Among the physical factors, the climate is responsible for high instability of wheat yield because sowing may be delayed due to the late planting of aman or use of long duration aman cultivars. This increases the risk of exposing the wheat crop to high temperature during the grain-filling stage in March/April and reduces grain yield (Selvaraju et al., 2006).

To estimate production variability of wheat due to drought occurrence in the study areas, semi-logarithmic regression model with dummy variable was employed.

Table 1. Effect of drought on wheat production

\begin{tabular}{lllll}
\hline Variable & Coefficient & Standard error & t value & Significant \\
\hline Constant & 3.281 & 0.069 & 47.69 & 0.000 \\
Dummy of Drought & -0.174 & 0.097 & -1.781 & 0.076 \\
\hline
\end{tabular}

It is evident from the Table 1 that wheat production was decreased by 17.4 percent on an average due to drought occurrence in the drought year in the study areas. In normal year wheat production increased due to favourable climate. 


\subsection{Technical Efficiency Model Analysis}

\subsubsection{Ordinary Least Square (OLS) Estimates of Cobb-Douglas (C-D) Stochastic Frontier Production Function}

The program FRONTIER 4.1 (Coelli, 1994) provides Maximum Likelihood (ML) estimates as well as Ordinary Least Squares (OLS) estimates for the parameters of Cobb-Douglas stochastic production function. Table 2 shows the OLS estimates of Cobb-Douglas stochastic production function for both drought and normal years of wheat production.

Table 2. OLS estimates of Cobb-Douglas (C-D) production function of wheat for normal and drought years

\begin{tabular}{|c|c|c|c|c|c|}
\hline \multirow{2}{*}{ Variable } & \multirow{2}{*}{ Parameters } & \multicolumn{2}{|c|}{ Normal year } & \multicolumn{2}{|c|}{ Drought year } \\
\hline & & Coefficient & Standard error & Coefficient & Standard error \\
\hline Intercept & $\beta_{0}$ & $4.0823 * *$ & 1.3520 & -0.1863 & 1.5042 \\
\hline Area & $\beta_{1}$ & 0.1934 & 0.2048 & 0.6708 & 0.2203 \\
\hline Seed & $\beta_{2}$ & $-0.5668^{* *}$ & 0.1319 & $0.6708^{* *}$ & 0.1334 \\
\hline Human labour & $\beta_{3}$ & -0.0649 & 0.1719 & -0.0693 & 0.1687 \\
\hline Pesticide & $\beta_{4}$ & $0.0077 * *$ & 0.0026 & -0.0016 & 0.0324 \\
\hline Tillage Cost & $\beta_{5}$ & 0.1230 & 0.1202 & $0.3227^{*}$ & 0.1486 \\
\hline Irrigation Cost & $\beta_{6}$ & -0.0473 & 0.0910 & 0.1012 & 0.0964 \\
\hline Manure & $\beta_{7}$ & 0.1968 & 0.5726 & -0.0982 & 0.0581 \\
\hline Fertilizer & $\beta_{8}$ & 0.1038 & 0.0904 & 0.0971 & 0.0911 \\
\hline Sigma squared & $\sigma^{2}$ & 0.0815 & & 0.0867 & \\
\hline Log Likelihood function & - & -0.1182 & & -14.9573 & \\
\hline
\end{tabular}

** indicates significant at $1 \% ; *$ indicates significant at $5 \%$.

The estimated values of the coefficient of seed, pesticide were positive and significant at $1 \%$ level for wheat in normal year. In case of drought year, seed and tillage were positively significant at $1 \%$ and $5 \%$ levels respectively. So it could be concluded that these three inputs were important factors for wheat production. The coefficient of irrigation was negative in normal year but positive in drought year indicating a scope of increasing productivity by raising the level of irrigation in drought year. Human labour and manure had negative but insignificant impact on wheat cultivation indicating excessive use of these inputs. The coefficient of area was positive in normal year but negative in drought year.

\subsubsection{Maximum Likelihood Estimates}

Table 3 shows the Maximum Likelihood estimates of the parameters of Cobb-Douglas stochastic production function and technical inefficiency effect model for both drought and normal years of wheat production. 
Table 3. ML estimates of the parameters of Cobb-Douglas stochastic frontier production function and technical inefficiency effect model for wheat

\begin{tabular}{|c|c|c|c|c|c|}
\hline \multirow{2}{*}{ Variable } & \multirow{2}{*}{ Parameters } & \multicolumn{2}{|c|}{ Normal year } & \multicolumn{2}{|c|}{ Drought year } \\
\hline & & Coefficient & Standard error & Coefficient & Standard error \\
\hline \multicolumn{6}{|l|}{ Stochastic production frontier } \\
\hline Intercept & $\beta_{0}$ & $1.2020^{*}$ & 0.5857 & 0.1602 & 1.0163 \\
\hline Area & $\beta_{1}$ & -0.3066 & 0.0687 & -0.2927 & 0.1479 \\
\hline Seed & $\beta_{2}$ & $0.5267 * *$ & 0.1201 & $0.6876^{* *}$ & 0.1128 \\
\hline Human labour & $\beta_{3}$ & 0.2216 & 0.166 & -0.1315 & 0.1405 \\
\hline Pesticide & $\beta_{4}$ & $0.0066^{* *}$ & 0.0020 & -0.0025 & -0.0030 \\
\hline Tillage Cost & $\beta_{5}$ & $0.2540 * *$ & 0.0671 & $0.2477^{*}$ & 0.0987 \\
\hline Irrigation Cost & $\beta_{6}$ & -0.0577 & 0.8302 & $0.2070^{* *}$ & 0.0579 \\
\hline Manure & $\beta_{7}$ & 0.0866 & 0.0622 & -0.0252 & 0.0537 \\
\hline Fertilizer & $\beta_{8}$ & $0.1772 * *$ & 0.0641 & $0.1700^{*}$ & 0.0793 \\
\hline \multicolumn{6}{|l|}{ Technical inefficiency model } \\
\hline Intercept & $\delta_{0}$ & $0.4665^{*}$ & 0.2258 & 0.2385 & 0.1980 \\
\hline Education & $\delta_{1}$ & 0.0186 & 0.0193 & $0.0502 *$ & 0.0199 \\
\hline Family size & $\delta_{2}$ & -0.0025 & 0.1263 & 0.0152 & 0.0293 \\
\hline Farming experience & $\delta_{3}$ & -0.0027 & 0.0089 & -0.0011 & 0.0089 \\
\hline Credit (dummy) & $\delta_{4}$ & -0.2835 & 0.1485 & $-0.2787^{*}$ & 0.1305 \\
\hline Extension contact (dummy) & $\delta_{5}$ & 0.0802 & 0.1438 & -0.1150 & 0.1180 \\
\hline Training (dummy) & $\delta_{6}$ & -0.0582 & 0.1331 & -0.1631 & 0.0928 \\
\hline Farm size & $\delta_{7}$ & -0.0065 & 0.0521 & -0.0890 & 0.0627 \\
\hline Sum of coefficients & - & 0.908 & - & 0.860 & - \\
\hline Sigma squared & $\sigma^{2}$ & $0.1101 * *$ & 0.02493 & $0.0677 * *$ & 0.0199 \\
\hline Gamma & $\gamma$ & $0.9999 * *$ & 0.00099 & 0.2315 & 0.6295 \\
\hline Log Likelihood function & - & 0.5817 & - & -0.4712 & - \\
\hline
\end{tabular}

** indicates significant at $1 \%$; indicates significant at $5 \%$.

The estimated values of the coefficient of seed, tillage cost and fertilizer were positive and significant for wheat production in both normal and drought years. Therefore, seed, tillage cost and fertilizer were productive inputs for successive production of wheat. The estimated value of the coefficient of pesticide was positive and significant for normal year. It implies that there exists a scope of increasing wheat production by enhancing the use of pesticide. For drought year the sign of the coefficient of pesticide was negative and insignificant. It would be due to overuse of this input in the drought year and gives an indication of declined productivity for using excessive pesticide.

Irrigation cost exhibits negative but insignificant effect in wheat production for normal year. It was positive and significant at $1 \%$ level for drought year. It indicates an opportunity to increase production by increasing the irrigation facilities in the field and by additional investment on irrigation equipments. Thus it further helps the wheat growers to reduce effect of drought on production. The finding is consistent with (Khan et al., 2010).

The coefficient of human labour and manure were positive but insignificant in wheat production for normal year, but these were negative and insignificant for drought year. It reveals that there is no scope of increasing production by further increase of those inputs in the drought year.

The estimated coefficient of area under wheat production was negative but insignificant for wheat production in both normal and drought years. It implies that wheat farmers were unable to manage and control their existing resources efficiently when large areas were devoted to wheat cultivation. 


\subsubsection{Factors Affecting Technical Inefficiency of Wheat Growers}

The sign of the $\delta$ parameters in the inefficiency effect model were expected to be negative. The negative signs of the coefficients imply their inverse effect on technical inefficiency and direct effects on technical efficiency. The effects of some socio-economic and demographic variables on technical efficiency included in technical inefficiency effect model (Table 3) were interpreted below:

\section{1) Farming Experience}

Farming experience of the farmer has a negative effect upon the inefficiency effects for wheat production in both the years. That is, technical inefficiency decreases with the increase of experience of the farmer. It indicates that experienced farmers were more efficient than less experienced ones in managing and allocating productive resources. Kamuzzaman and Islam (2008) observed similar results and argued that the farmers with more experience tend to be more efficient.

\section{2) Farm Size}

The coefficient of farm size in the inefficiency effect model was negative in the normal year which indicates that technical inefficiency of wheat producing farmers decreases as the farm size increases. But it was positive in the drought year which indicates that farmers become more inefficient to manage the adverse situation due to drought as the farm size increases.

3) Credit

The coefficient of credit was negative and significant for wheat production in drought year indicating that technical inefficiency decreases with increase of credit utilization in wheat farming. It also indicates that credit receivers were more efficient than non-receivers. The coefficient of credit was also negative in normal year. Similar result was observed by Ali et al. (1999) who argued that availability of credit played significant role in improving technical efficiency of farmers.

\section{4) Extension Contact}

The coefficient of extension contact was negative but insignificant in the inefficiency effect model for wheat production in drought year. The negative coefficient means that technical inefficiency effect decreases with the increase in the number of extension contacts of extension agents with the farmers. It also means that farmers with more extension contacts tend to have smaller technical inefficiencies than farmers with less extension contacts. The result is consistent with Ali et al. (1999); Kamuzzaman and Islam (2008). But in case of normal year coefficient of extension contact was positive but insignificant. The result also reveals that although extension contact helps to increase technical efficiency of the farmers but it was not significant. So, Department of Agricultural Extension should strengthen their activities by providing up-to-date information regarding modern technology and increasing extension contact with the farmers.

\section{5) Training}

The coefficient of training was negative but insignificant in the technical inefficiency effect model for wheat production in both the years. This implies that technical inefficiency decreases with the farmers who received training on agriculture. That means trained farmers were more efficient than non-trained farmers. This finding is consistent with Hasan and Islam (2010).

\section{6) Education}

The sign of the coefficient of education was positive and insignificant in normal year. It was also positive but significant in drought year which was unexpected but not surprising. It means that technical inefficiency increases with increase in education level. One of the reasons may be that most of the educated farmers were found to have alternative income sources (service, business etc) and they are not very attentive to the farming practices. Another reason is that most of the educated farmers are village leaders and they were found to be busy with the problem of villagers and many of them were also engaged in politics. For that reasons they have devoted little time to their farming practices. Similar result was observed by Rahman (2002) where the sign of the coefficient of education was positive in the technical inefficiency effect model.

\section{7) Family Size}

Family size has negative but insignificant impact on technical inefficiency of wheat growers in both the years which implies that technical inefficiency decreases with increase in family size. Similar result was observed by (Hasan \& Islam, 2010).

Dominance of inefficiency effect over random error can easily be visualized from the significant values of 
gamma $(\gamma)$ in Table 3. The $\gamma$ parameter associated with the variances in the stochastic frontier is significant for wheat production in normal year. It indicates that there were inefficiency effects in wheat production and the random component of the inefficiency effects made a significant contribution to the analysis of wheat production. The $\gamma$ was insignificant for drought year which means inefficiency effects were present but not significant for wheat production in the year of drought occurrence. It implies that wheat farmers used their existing resources more efficiently in drought year than normal year to reduce the harmful effect of drought on wheat production.

The estimates of $\sigma^{2}$ (the ratio of the variance of farm specific technical efficiency to the total variance of output) were 0.1101 for normal year and 0.0677 for drought year and both were significant at $1 \%$ level. These suggest that the technical inefficiency effects were a momentous component to the total variability of the yield of wheat crops.

\subsubsection{Efficiency Scores of Wheat Growers}

The frequency distribution of the technical efficiency estimates of the farmers obtained from Cobb-Douglas stochastic frontiers for wheat production in normal and drought years were shown in Table 4.

Table 4. Frequency distribution of technical efficiencies of the wheat growers

\begin{tabular}{|c|c|c|}
\hline \multirow{2}{*}{ Efficiency level (\%) } & \multicolumn{2}{|c|}{ No. of farmers } \\
\hline & Normal year & Drought year \\
\hline \multirow{2}{*}{$10-20$} & 1 & 0 \\
\hline & $(1.00)$ & $(0.00)$ \\
\hline \multirow{2}{*}{$20-30$} & 0 & 0 \\
\hline & $(0.00)$ & $(0.00)$ \\
\hline \multirow{2}{*}{$30-40$} & 2 & 0 \\
\hline & $(2.00)$ & $(0.00)$ \\
\hline \multirow{2}{*}{$40-50$} & 12 & 1 \\
\hline & $(12.00)$ & $(1.00)$ \\
\hline \multirow{2}{*}{$50-60$} & 27 & 6 \\
\hline & $(27.00)$ & $(6.00)$ \\
\hline \multirow{2}{*}{$60-70$} & 17 & 7 \\
\hline & $(17.00)$ & $(7.00)$ \\
\hline \multirow{2}{*}{$70-80$} & 14 & 8 \\
\hline & $(14.00)$ & $(8.00)$ \\
\hline \multirow{2}{*}{$80-90$} & 15 & 23 \\
\hline & $(15.00)$ & $(23.00)$ \\
\hline \multirow{2}{*}{$90-100$} & 12 & 55 \\
\hline & $(12.00)$ & $(55.00)$ \\
\hline Total & 100 & 100 \\
\hline Mean efficiency & 67.00 & 86.4 \\
\hline Maximum efficiency & 99.8 & 98.5 \\
\hline Minimum efficiency & 16.7 & 48.7 \\
\hline
\end{tabular}

Values within parentheses indicate percentages.

It is observed from the Table 4 that technical efficiency varied from 16.7 to 99.8 percent for wheat growers in normal year. On the other hand, technical efficiency varied from 48.7 to 98.5 percent in drought year.

The mean technical inefficiency was 67.00 percent for wheat growers in normal year and in drought year mean 
efficiency of wheat growers was 86.4 percent which indicating that farmers were 19.4 percent more efficient in drought year than that of normal year.

It is evident that technical efficiency of wheat growers in normal year was distributed over a range from 10 to 100 and maximum farmers (27 percent) belonged to technical efficiency range 50 to 60 . Only 12 percent of farmers belonged to a high technical efficiency range 90 to 100 but in case of drought year 55 percent farmers belonged to this technical efficiency range 90 to 100. It is also observed from the Table 4 that for drought year range of technical efficiency was distributed from 40 to 100 which was relatively squeezed than normal year. It implies that wheat growers were more efficient in using existing inputs, technology to produce maximum output in drought year.

\subsubsection{Test of Hypotheses}

The null hypothesis is that the inefficiency effects are not present, $\mathrm{H}_{0}: \gamma=\delta_{0}=\ldots \delta_{7}=0$ and the coefficients of the variables in the model for the inefficiency effects are zero, $\mathrm{H}_{0}: \delta_{1}=\ldots \delta_{7}=0$ were tested using the generalized likelihood ratio statistic LR defined in Equation (10). It is imperative, according to Coelli (1995), to perform one sided generalized likelihood ratio test when Maximum Likelihood estimation is involved because this test has the correct size (i.e. probability of type I error).

Table 5. Testing the null hypotheses involving the parameters of the technical inefficiency effect model

\begin{tabular}{llllll}
\hline Null hypothesis & Log likelihood value & Degrees of freedom $(\mathrm{df})$ & Test statistic LR & Critical value $\left(\chi_{0.05}^{2}\right)$ & Decision \\
\hline $\mathrm{H}_{0}: \gamma=\delta_{0}=\ldots=\delta_{7}=0$ & & & & & Rejected \\
Normal year & 0.5817 & 9 & 24.808 & 16.91 & Rejected \\
Drought year & -0.4712 & 9 & 28.972 & 16.91 & Rejected \\
$\mathrm{H}_{0}: \delta_{1}=\ldots=\delta_{7}=0$ & & & & & 15.51 \\
Normal year & -3.3672 & 7 & 16.299 & 15.51 & Rejected \\
Drought year & -1.0189 & 7 & 27.876 & & \\
\hline
\end{tabular}

The result of the hypothesis test presented in Table 5 reveals that there was significant technical inefficiency effect for wheat production in both normal and drought years since the null hypothesis is rejected for both years. This indicates that the average response function is not an adequate representation of wheat production in the study areas. Another null Hypothesis $\mathrm{H}_{0}: \delta_{1}=\ldots \delta_{7}=0$ considered is also rejected for wheat production in both years. Hence, it could be concluded that the efficiency effects are significantly influenced by the variables included in the inefficiency model.

\section{Conclusion and Policy Implications}

The findings of the study showed that wheat growers were efficient in wheat production and able to produce maximum output with existing inputs. Climate change affected adversely the production of wheat and reduced output level. On an average, wheat production has decreased by 17.4 percent due to drought during the drought year in the study areas. Mean technical efficiency estimated by Cobb-Douglas stochastic frontier function showed that there was a huge potential for increasing wheat production through the improvement of technical efficiency of wheat growers in the normal and drought years. The findings also showed that the farmers were more efficient in drought year than normal year. Farmers were more efficient in using existing inputs and technology to cope with adverse effect of climate change on production.

In order to increase production, farmers should be provided additional training on climate change adaptation strategies, extension services, micro- credit to operate their farm efficiently. The government of Bangladesh should take the initiative to extend agricultural extension services to the farmers in order to enhance sustainable agricultural growth. Supply of quality seeds to the farmers should be ensured by strengthening seed production and distribution system with the combined efforts of public and private sectors. High price of fertilizers affected the application of fertilizer in wheat field. In this regard, government should take necessary action for supplying sufficient fertilizers to the farmers in time at an affordable price. Initiatives related to climate change adaptations should be made through field-level application and community involvement. Government should give the most immediate attention for creating awareness among farmers about vulnerability to climate change and to increasing drought frequencies. Integrated efforts should be made by the government as well as NGOs and 
international organizations to mitigate the impact of drought.

\section{References}

Aigner, D. J., Lovell, C. A. K., \& Schimidt, P. J. (1977). Formulation and Estimation of Stochastic Frontier Production Function Models. Journal of Econometrics, 6, 21-37. http://dx.doi.org/10.1016/0304-4076(77)90052-5

Ali, M., Ahamad, M., \& Rafiq, M. (1999). An Analysis Technical Inefficiency of Rice Farmers in Pakistan: Panjab. Bangladesh Journal of Agricultural Economics, 22, 79-86.

Banglapedia. (2003). National Encyclopedia of Bangladesh. Asiatic Society of Bangladesh, 3, 390-391.

Battese, G. R., \& Coelli, T. J. (1993). A Stochastic Frontier Production Function Incorporating a Model for Technical Efficiency Effect. Working paper in Econometrics and Applied Statistics. No. 69, Department of Econometrics, University of New England, Armidale, 2351, Australia.

Battese, G. E., \& Coelli, T. J. (1995). A model for technical inefficiency effects in a stochastic frontier production function for panel data. Empirical Economics, 20, 325-332. http://dx.doi.org/10.1007/BF01205442

BBS, (1980). Statistical Year Book of Bangladesh. Bangladesh Bureau of Statistics, Ministry of Planning, Government of the People's Republic of Bangladesh, Dhaka.

BBS Labour Force Survey Report. (2005-2006). Bangladesh Bureau of Statistics. Ministry of planning, Government of the people's Republic of Bangladesh, Dhaka.

BBS, (2008). Statistical Year Book of Bangladesh. Bangladesh Bureau of Statistics, Ministry of planning, Government of the people's Republic of Bangladesh, Dhaka.

Chamse, A. W., Cooper, W., \& Rhodees, E. (1978). Measuring the Efficiency of Decision Making Units. European Journals of Operational Research, 2, 429-444. http://dx.doi.org/10.1016/0377-2217(78)90138-8

Coelli, T. J. (1994). A Guide to FRONTIER Version 4.1 A Computer Programme for Stochastic Frontier Production and Cost Function Estimation. Depertment of Econometrics, University of New England, Armidale, NSW 2351, Australia.

Coelli, T. J. (1995). Recent Development in Frontier Modeling and Efficiency Measurement. Australian Journals of Agriculture Economics, 39, 215-245.

Coelli, T. J., \& Battese, G. E. (1996). Identification of Factors which Influence the Technical Inefficiency of Indian Farmers. Australian Journals of Agricultural Economics, 40(2), 103-128. http://dx.doi.org/10.1111/j.1467-8489.1996.tb00558.x

Coelli, T. J., Rao, D. S. P., \& Battese, G. E. (1998). An Introduction of Efficiency and Productivity Analysis. Kluwer Academic Publishers, Boston, USA. http://dx.doi.org/10.1007/978-1-4615-5493-6

Craig, A. M. (1992). Impact of Crop Management Research in Bangladesh. Wheat Special Report No.3. CIMMYT, Mexico, D. F., Mexico.

Dillon, J. I., \& Hardaker, J. B. (1993). Farm Management Research for Small Farmer Development. FAO, Agricultural Services Bulletin 41, Food and Agricultural Organization of the United Nations, Rome.

Farrel, M. J. (1957). The Measurement of Productive Efficiency. Journal of Royal Statistical Society, 120(3), 253-281. http://dx.doi.org/10.2307/2343100

FPMU. (2008). Food Budget. Food Planning and Monitoring Unit, Ministry of Food and Disaster Management, Government of the People's Republic of Bangladesh.

Green, W. H. (1990). A Gamma Distributed Stochastic Frontier Model. Journal of Econometrics, 13, 101-116.

Hasan, M. K., \& Islam, S. M. F. (2010). Technical Inefficiency of Wheat Production in Some Selected Areas of Bangladesh. Bangladesh Journal of Agricultural Research, 35(1), 101-112. http://dx.doi.org/10.3329/bjar.v35i1.5871

Huang, C. L., \& Lui, J. T. (1994). Estimation of a Non-neutral Stochastic Frontier Function. Journal of Productivity Analysis, 46, 171-180. http://dx.doi.org/10.1007/BF01073853

Johnston, J. (1984). Econometric Methods (3rd ed.). New York, NY: McGraw-Hill. 
Kamruzzaman, M., \& Islam, M. H. (2008). Technical Efficiency of Wheat Growers in Some Selected Sites of Dinajpur District of Bangladesh. Bangladesh Journal of Agricultural Research, 33(3), 363-373. http://dx.doi.org/10.3329/bjar.v33i3.1595

Khan, A., Huda, F. A., \& Alam, A. (2010). Farm Household Technical Efficiency: A Study on Rice Producers in Selected Areas of Jamalpur District in Bangladesh. European Journal of Social Sciences, 14(2), 262-271.

Khan, M. A. (2003). An Economic Analysis of Fish Hathery Management in Selected Areas of Bangladesh. European Journal of Social Sciences, 14(2), 262-271.

Meeusen, W., \& Van den Broeck, J. (1977). Efficiency Estimation from Cobb-Douglas Production Functions with Composite Error. International Economic Review, 18, 435-444. http://dx.doi.org/10.2307/2525757

Quazi, N. U., \& Quddus, K. M. G. (2010).'Climate Chenge in Bangladesh (Term Paper). StudyMode.com. Retrieved from http://www.studymode.com/essays/Climate-Chenge-In-Bangladesh-1164777.html

Rahman, K. M. M. (2002). Measuring Efficiency in Producing Rice in Bangladesh: A Stochastic Frontier Analysis. Wissenschaftsverlag Vauk Kiel KG, Germany.

Selvaraju, R., Subbiah, A. B., Baas, S., \& Juergens, I. (2006). Livelihood Adaptation to Climate Variability and Change in Drought - Prone Areas of Bangladesh. Institutions for Rural Development Series (No. 5, p. 33). Food and Agriculture Organization of the United Nations, Rome, Italy.

Sharma, K. R., \& Leung. (1998). Technical Efficiency of Carp Production in Nepal: An Application of Stochastic Frontier Production Function Approach. Aquaculture Economics and Management, 2(3), 129-140. http://dx.doi.org/10.1080/13657309809380224

\section{Copyrights}

Copyright for this article is retained by the author(s), with first publication rights granted to the journal.

This is an open-access article distributed under the terms and conditions of the Creative Commons Attribution license (http://creativecommons.org/licenses/by/3.0/). 